\title{
The Distribution of Acetylcholinesterase(AChE)-Positive Nerves in Chicken Pancreas Demonstrated by Light and Electron Microscopy*
}

\author{
Kohzy Hiramatsu, Tohru Watanabe and Toshitake Fujioka \\ Department of Veterinary Anatomy, Faculty of Agriculture, Nagoya University, Nagoya, Japan
}

Received October 21, 1987

Summary. The distribution of acetylcholinesterase (AChE)-positive nerve fibers in the chicken pancreas was investigated with histochemical methods at the light and electron microscopic level. AChE-positive nerve bundles were found to run along the pancreaticoduodenal artery and their branches proceed into interlobular connective tissue, form a plexus around the interlobular secretory ducts and small arteries, and penetrate the exocrine parenchyma. Intrapancreatic ganglia showing a strong AChE activity were detected within the interlobular connective tissue or between acini. The exocrine pancreas was richly innervated with AChEpositive terminals which contained a few large densecored vesicles (about $100 \mathrm{~nm}$ in diameter) and many small clear vesicles (about $50 \mathrm{~nm}$ in diameter). Such terminals made contact with intercalated ductular cells and the smooth muscles of larger blood vessels. The endocrine pancreas was supplied with fewer nerves than the exocrine pancreas. A different distribution of AChEpositive fibers was noticed between $A$ - and B-islets which were distinguished immunohistochemically. Band D-cells were richly innervated by AChE-positive nerves, whereas A-cells, only poorly. These observations make clear that the cholinergic system relates to the regulation of both exocrine and endocrine tissues, except A-cells, in the chicken pancreas.

Only a few studies have been available on the innervation of the avian pancreas (WATARI, 1968, pigeon; KOBAYASHI and FUJITA, 1969, pigeon; KUDO, 1971, chicken; DAHL, 1973, chicken; Smith, 1974, quail; PURWAR, 1974, chicken, 1976, grey partridge; TRANDABURU, 1974, pigeon and magpie; WATANABE and YASUDA, 1977, chicken), presenting information that no nervous elements were found in avian pancreatic islets even at the electron microscopic level. Nerve fibers exhibiting cholinesterase activity were found in both the exocrine and endocrine pancreas of the domestic fowl (PURWAR, 1974) and grey partridge (PURWAR, 1976). In his ultrastructural and acetylcholinesterase (AChE) histochemical investigations in the pigeon and magpie, TRANDABURU (1974) pointed out that there was a rich supply of nerves in the exocrine pancreas, but a lack of innervation in the islets. In the domestic fowl, we were able to divide nerve terminals in the exocrine and endocrine pancreas into four types, based on a combination of the three kinds of synaptic vesicles (WATANABE and YASUDA, 1977). We assumed the terminals containing small clear synaptic vesicles to be cholinergic in nature. More systematic investigations, however, were considered necessary for a better knowledge of the innervation characteristics of the avian pancreas.

The present study aims at the elucidation of the distribution pattern of AChE-positive nerves in both the exocrine and endocrine pancreas of the domestic fowl at the light microscopic level, and of the type of AChE-positive nerve terminals at the electron microscopic level. Particular attention is paid to differences in the distribution of AChE-positive nerves in two kinds of islets, $\mathrm{A}$ and $\mathrm{B}$, of the domestic fowl.

\section{MATERIALS AND METHODS}

Twenty adult male domestic fowls (White Leghorn), weighing $1.4-2.2 \mathrm{~kg}$, were used in the present study. Immediately after sacrifice, the tails of the pancreata were quickly dissected out.

\footnotetext{
*This work was supported by scientific grants (Nos. 59560260 and 60560280) to T. W. from the Ministry of Education, Science and Culture, Japan.
} 


\section{Light microscopic demonstration of AChE}

Specimens from 11 chickens were immediately frozen in isopentane chilled by liquid nitrogen. After freezing they were serially cut into $14 \mu \mathrm{m}$ thick sections using a cryostat in a transverse plane and mounted on gelatin-coated glass slides. The sections were air-dried for a few minutes and processed for demonstration of AChE activity according to the directcoloring thiocholin method (KARNOVSKY and ROOTS, 1964) modified by NAKAMURA and TORIGOE (1979). Incubation was carried out for $2 \mathrm{~h}$ at $4^{\circ} \mathrm{C}$. As an inhibitor of non-specific cholinesterase, $2 \times 10^{-4} \mathrm{M}$ tetraisopropyl pyrophosphoramide (iso-OMPA; Sigma, USA) was used. After incubation, the sections were rinsed in $30 \%$ sucrose and immersed in an enhancementmedium containing $0.01 \%$ rubeanic acid. Following their rinsing in $50 \%$ sucrose, the preparations were dried in a desiccator under $\mathrm{P}_{2} \mathrm{O}_{5}$ for more than $4 \mathrm{~h}$ and mounted in Entellan. Observations were made with a standard light microscope.

\section{Identification of islets by immunohistochemistry}

To identify A- and B-islets, the serial frozen section adjacent to a section stained with $\mathrm{AChE}$ histochemistry was fixed in $10 \%$ neutral formalin at $4^{\circ} \mathrm{C}$ overnight. After several rinsings with distilled water, the sections were stained immunohistochemically with peroxidase-antiperoxidase glucagon and insulin kits obtained commercially from Milab (Malmö, Sweden) and BioGenex Laboratories (Dublin, USA), respectively. After immunohistochemical staining, the sections were counterstained with Mayer's hematoxylin, dehydrated, cleared in xylene, and mounted. They were examined and photographed with a light microscope. These two procedures made it possible to observe differences in the distribution of AChEpositive nerve fibers in two kinds of pancreatic islets.

\section{Electron microscopic demonstration of $A C h E$}

For cytochemical localization of $\mathrm{AChE}$, the pancreata of nine chickens were immersed in $2 \%$ glutaraldehyde in $50 \mathrm{mM}$ sodium cacodylate buffer $(\mathrm{pH} 7.3)$ containing $10 \%$ sucrose at $4^{\circ} \mathrm{C}$, trimmed into small blocks, and then fixed for $2 \mathrm{~h}$ in the same solution at $4^{\circ} \mathrm{C}$. Tissue blocks were rinsed in $50 \mathrm{mM}$ sodium cacodylate buffer containing $0.8 \%$ sodium sulfate and $10 \%$ sucrose, to then be cut at $50 \mu \mathrm{m}$ thickness with a Sorvall TC-2 tissue-sectioner. The copper-thiocholine method (LEwIS and SHUTE, 1969) was applied as the cytochemical procedure to demonstrate $\mathrm{AChE}$ activity. Non-specific esterase was inhibited with $2 \times 10^{-4}$ $\mathrm{M}$ iso-OMPA. Specimens were post-fixed for $2 \mathrm{~h}$ in
$1 \%$ osmium tetroxide in $0.1 \mathrm{M}$ phosphate buffer at $4^{\circ}$ $\mathrm{C}$, dehydrated through a graded ethanol series and embedded in Epon-812. The ultrathin sections, either double-contrasted with uranyl acetate and lead citrate or not contrasted at all, were examined and photographed with a JEM-100S electron microscope.

\section{RESULTS}

\section{Light microscopy}

Since rubeanic acid reacts with copper compounds to form greenish black precipitates, AChE-positive nerve fibers can be observed as greenish black fibers under the light microscope.

AChE-positive nerve bundles were found in the connective tissue surrounding the branches of the pancreaticoduodenal artery (Fig. 1). In the adventitia of blood vessels, nerve fibers ran parallel to them. These nerve fibers showed a strong AChE activity (Fig. 1). Many AChE-positive fibers and bundles were located in the interlobular connective tissue near the arteries (Fig. 2).

In the exocrine parenchyma, AChE-positive fibers were abundant in both the dorsal and ventral lobes of the pancreas. Such nerve fibers were seen running freely between acini (Fig. 3). In the splenic lobe, however, they were very sparse, with most of them located around secretory ducts.

Intrapancreatic ganglia of various shapes and sizes appeared in the interlobular connective tissue or between acini. They showed a strong reaction for $\mathrm{AChE}$ (Fig. 4). Two kinds of fibers were detected near such ganglia. One was strongly AChE-positive, while the other had very weak activity for AChE (Fig. 4, arrowhead). No AChE-positive ganglia were found in the splenic lobe.

Large extralobular secretory ducts possessed a great many $\mathrm{AChE}$-positive nerve fibers running circularly in their smooth muscle layer. The muscle layer of the intralobular secretory ducts also received AChE-positive nerve fibers. However, many more nerve fibers were found in the muscle layer of the intrapancreatic ducts (Figs. 5a, 6a) than in that of the extralobular secretory ducts. These formed a periductular plexus from which the AChE-positive nerve fibers penetrated into the exocrine tissue.

Cell clusters showing a weak AChE activity were readily found in the splenic lobe (Fig. 5a). They were identified as A-islets because they also showed glucagon immunoreactivity on adjacent serial sections (Fig. 5b). AChE-positive nerve fibers in A-islets were seen to run along islet capillaries (Fig. 5a). The 

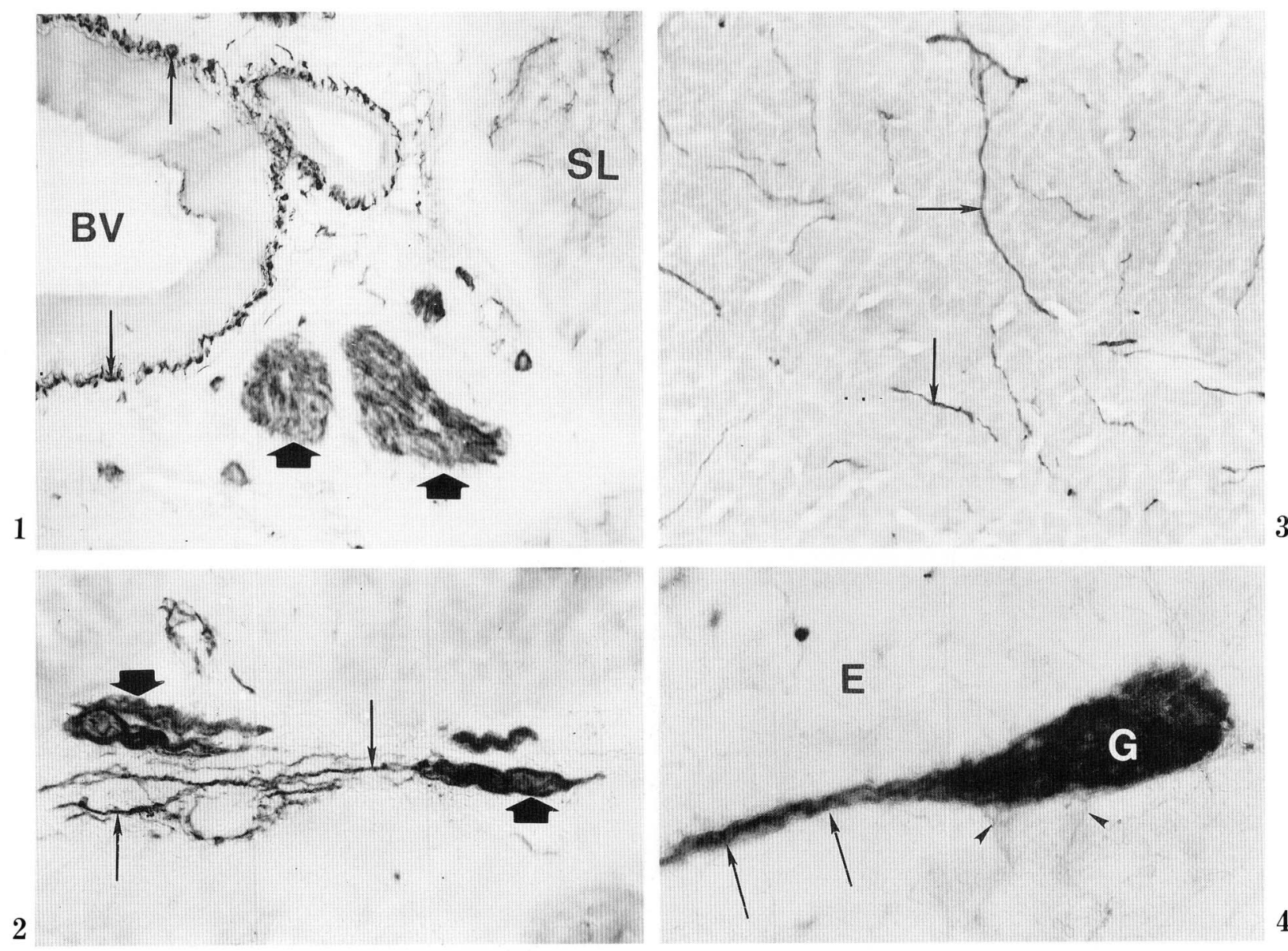

Fig. 1. AChE-positive nerve bundles (large arrows) along blood vessels $(B V)$ in the connective tissue surrounding the splenic lobe (SL). The vascular wall contains many AChE-positive nerves (small arrows). $\times 85$

Fig. 2. AChE-positive nerve bundles (large arrows) and fibers (small arrows) along the blood vessels in the interlobular connective tissue. $\times 186$

Fig. 3. AChE-positive fibers (arrows) scattered in the exocrine parenchyma of the dorsal lobe. $\times 225$

Fig. 4. An intrapancreatic ganglion $(G)$ exhibiting intense AChE activity. Two kinds of nerve bundles can be detected near the ganglion. One shows intense AChE activity (arrow), while the other is weakly AChE-positive (arrowhead). E exocrine tissue. $\times 170$

peri-insular distribution of AChE-positive nerve fibers was seldom found in A-islets.

B-islets identified by the insulin immunoreactivity on the adjacent serial section (Fig. 6b) never showed any $\mathrm{AChE}$ activity in endocrine cells (Fig. 6a). Nerve fibers in B-islets were obviously different in distribution from those in A-islets. AChE-positive nerves around B-islets generally formed a peri-insular plexus which issued branches penetrating the islet (Fig. 6a).

\section{Electron microscopy}

Ganglion cells were easily identified by electron microscopy. A positive $\mathrm{AChE}$ reaction was detected between the nuclear envelopes, in the cisternae of the rough endoplasmic reticulum, and on a part of the plasma membrane of the cell (Fig. 7a). The lumen of the Golgi lamellae also showed AChE activity in both cis- and trans-leaflets, though sometimes only in the latter (Fig. 7b). Terminals containing many small clear vesicles contacted the ganglion cell soma showing AChE activity. A few terminals which contained many large dense-cored vesicles, supposedly preganglionic fibers, displayed AChE activity around the axolemma or ganglion cell soma (Fig. 7c). Most of the unmyelinated axons in the neuropile around the ganglion cells showed AChE activity. Reaction products were located in the peri-axolemmal cleft or space and also in spaces of the endoneurium (Fig. 7d). 

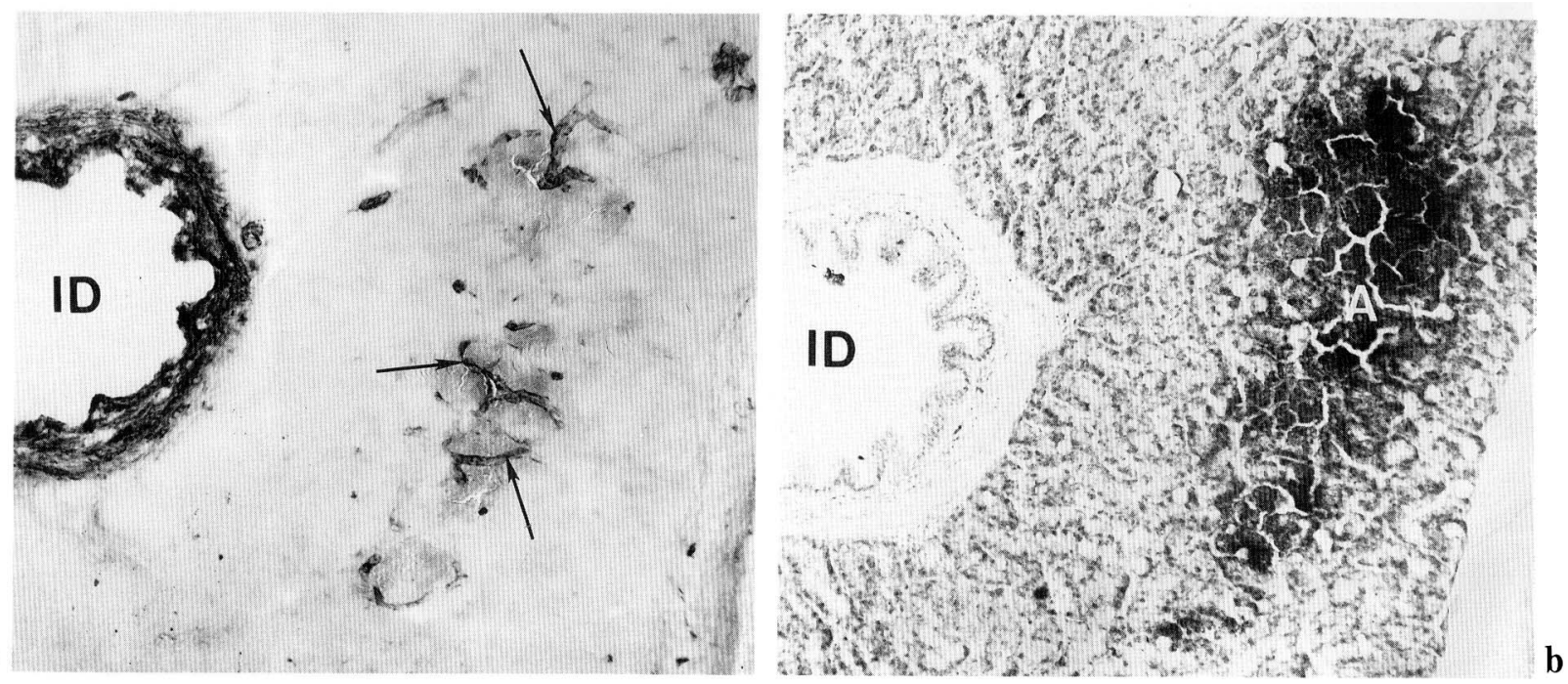

Fig. 5. The distribution of AChE-positive nerve fibers in the A-islet. a. AChE-positive nerve fibers (arrows) are seen in a cell cluster showing weak AChE activity. Many AChE-positive fibers are also shown in the muscle layer of an intraparenchymal secretory duct $(I D) . \times 85$. b. Immunohistochemical reaction with anti-glucagon serum in a section adjacent to that shown in Fig. 5a. The cell cluster showing the AChE activity in Fig. 5a is glucagon immunoreactive $(A) . \times 85$

$\mathbf{a}$
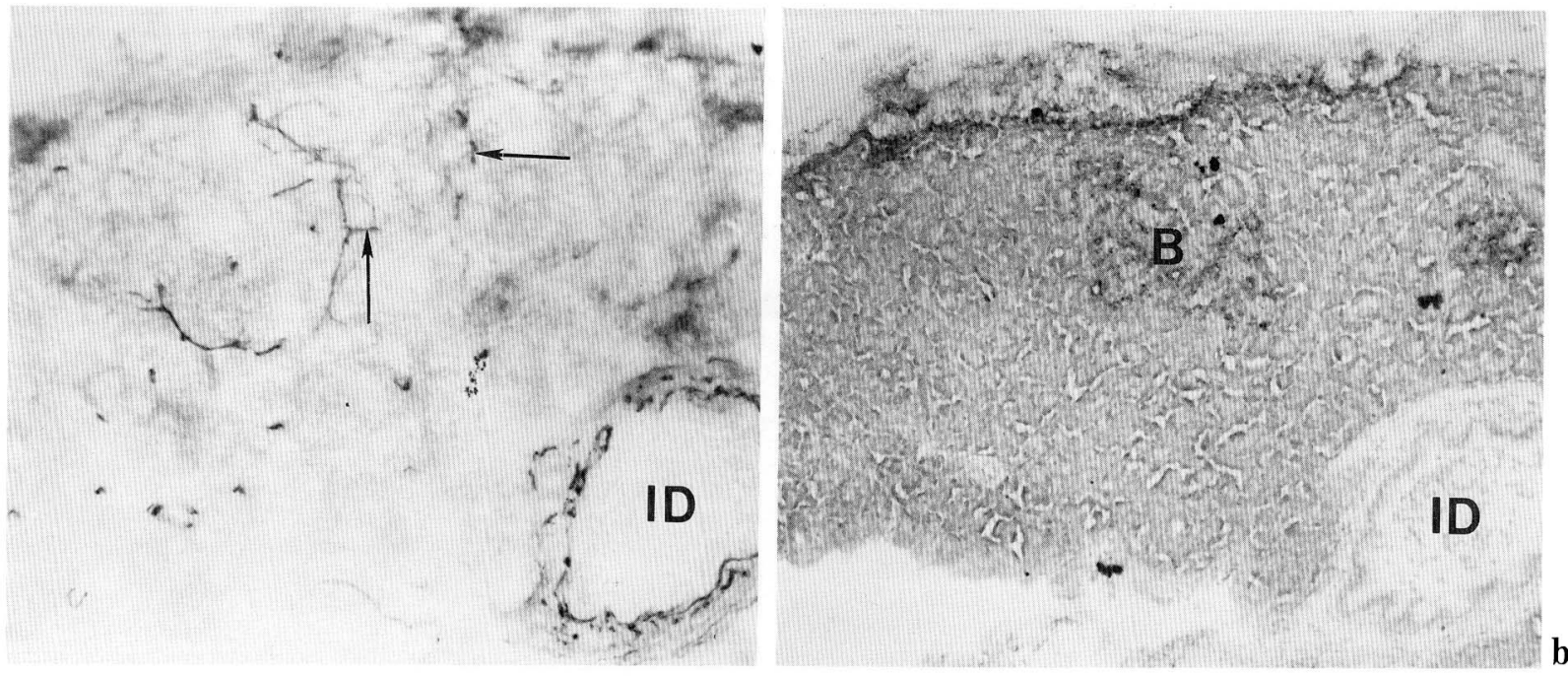

Fig. 6. The distribution of AChE-positive fibers (arrows) in a B-islet. a. The AChE-positive periinsular plexus surrounds a B-islet and issues a few fibers (arrows) penetrating it. $\times 85$. b. Immunohistochemical reaction with anti-insulin serum in a section adjacent to that of Fig. 6 a. $B$ B-islet. $\times 85$

Fig. 7. Ultrastructural observation of a ganglion cell found between acini. a. A ganglion cell shows intense AChE activity at its nuclear envelope, in the cisternae of the rough endoplasmic reticulum and Golgi lamellae and a part of plasma membrane. $G$ ganglion cell, $N$ nucleus. $\times 7,200$. b. AChE-positive Golgi apparatus in a ganglion cell. $\times 42,000$. c. An AChE-positive nerve terminal (arrow in Fig. 7a) contacting a ganglion cell soma. It contains many large dense-cored vesicles. $G$ ganglion cell. $\times 28,500$. d. AChE-positive fibers near a ganglion cell. The reaction products are seen in spaces of the endoneurium and in the outer surface of the membrane of a few nerve fibers. $\times 9,900$ 

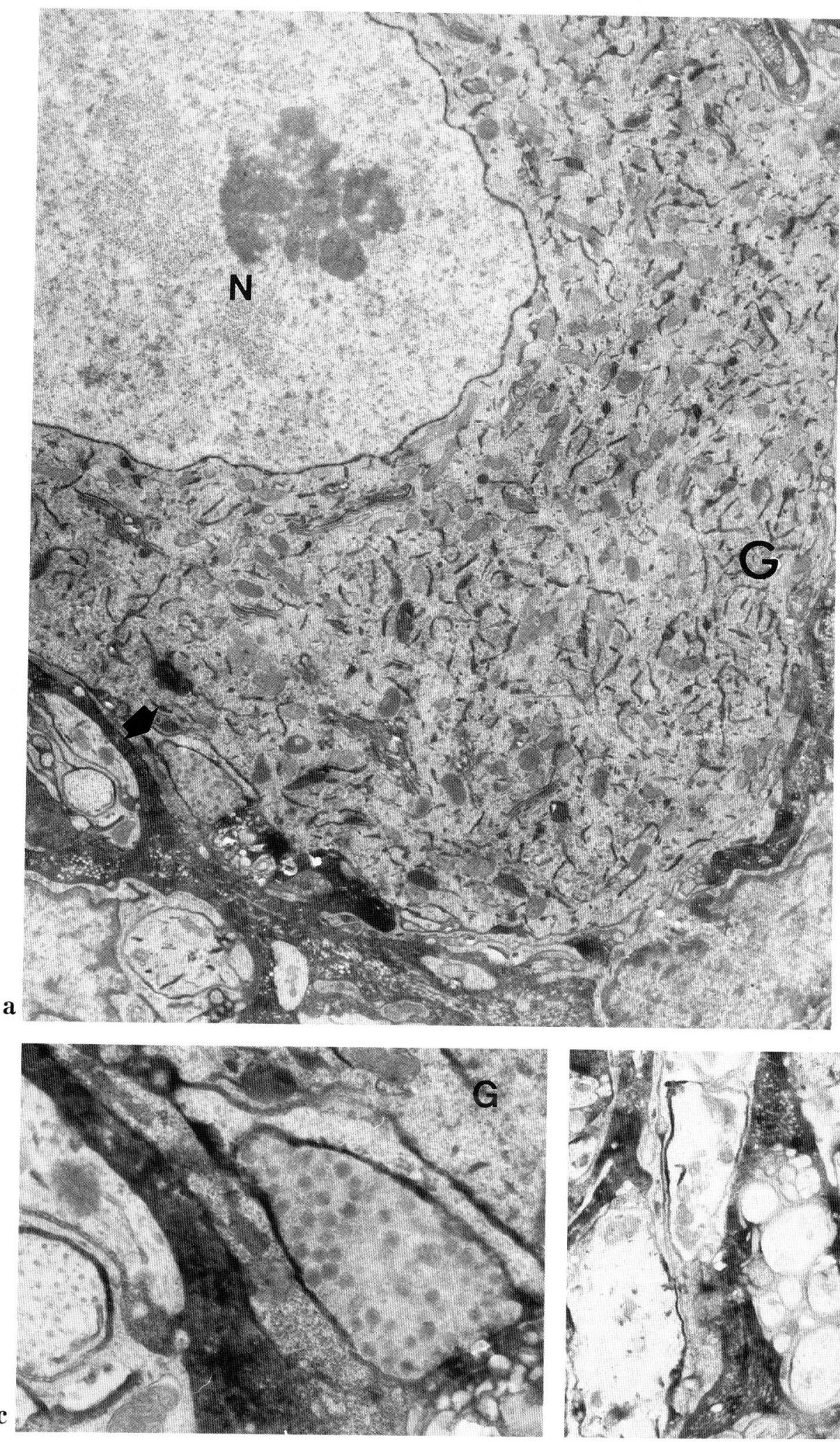
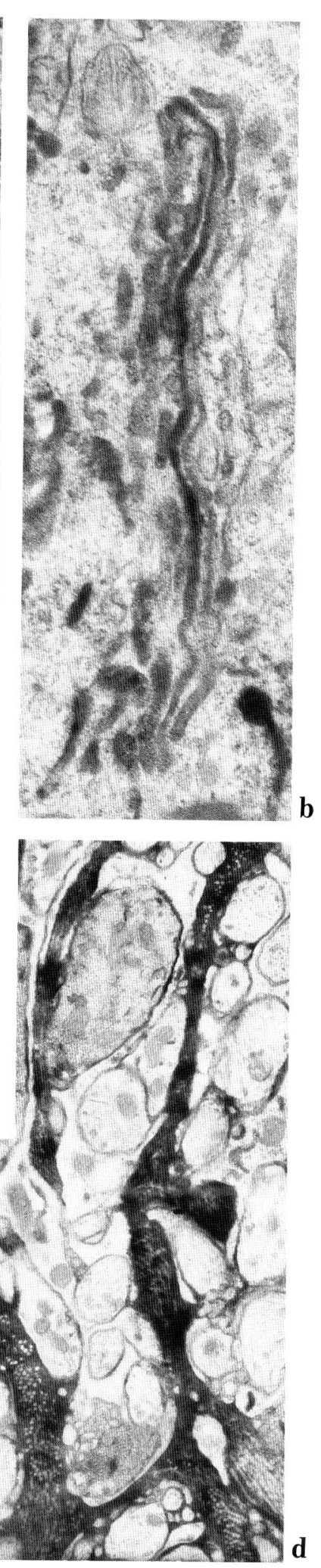

Fig. 7. Legend on the opposite page. 
AChE-positive nerve fibers were also recognized between small arteries and acini, and terminated on the endothelium (Fig. 8) and the acinus.

Unmyelinated nerve bundles supported by Schwann cells were observed in the exocrine parenchyma. They seemed to originate from the perivascular plexus, then threading their way between acini (Fig. 9a). Varicosities were formed along these bundles outside the basement membrane of acinar cells. Such varicosities contained a few large dense-cored vesicles and many small clear vesicles (Fig. 9b). AChE activity was observed along the periaxolemma of these varicosities, but not in the vesicles contained in them. Occasionally a few large dense-cored vesicles

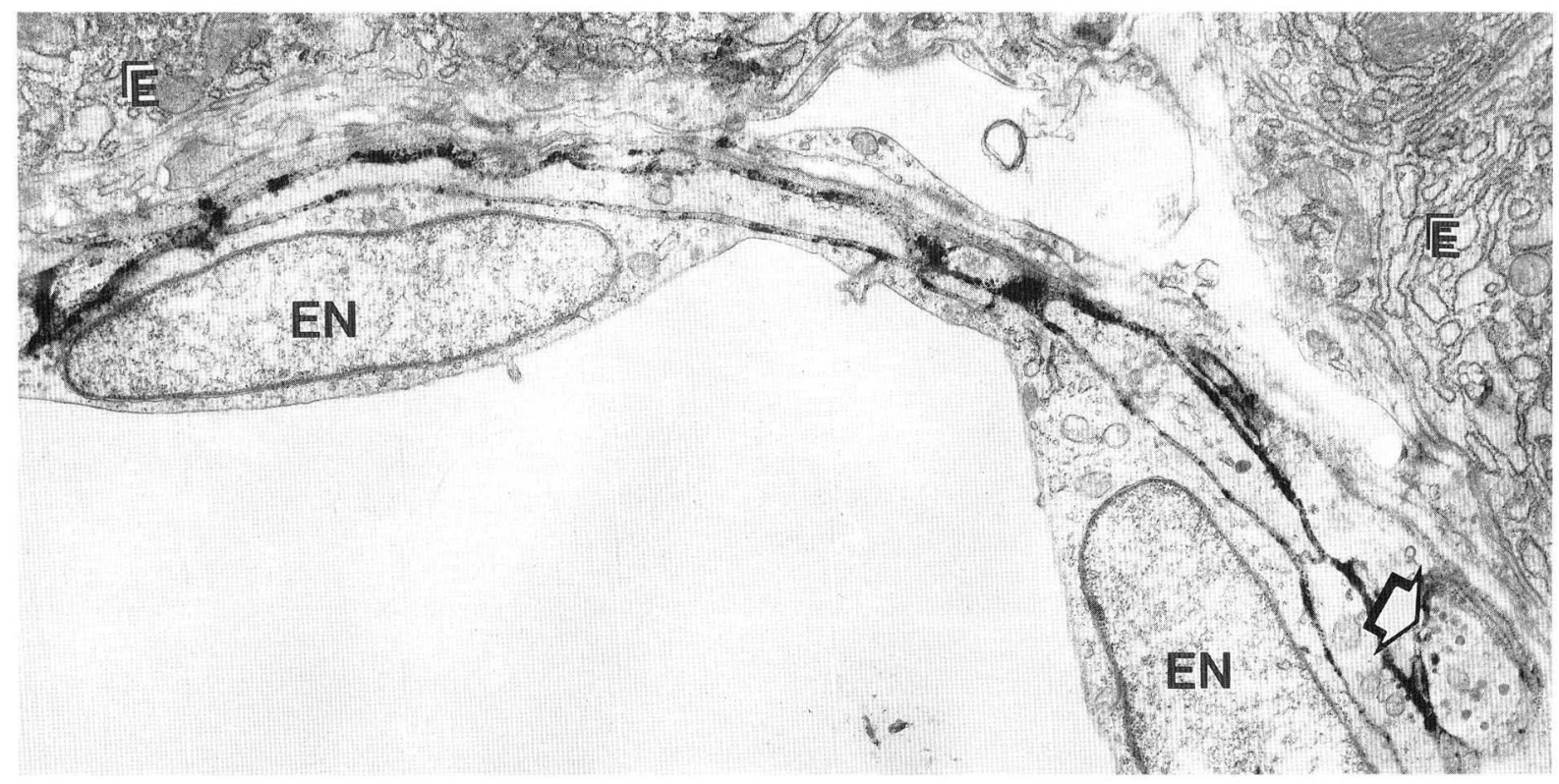

Fig. 8. AChE-positive nervous elements around an artery. The arrow indicates nerve terminals containing several large dense-cored vesicles and small clear vesicles. $E N$ nucleus of endothelial cell. $E$ exocrine tissue. $\times 9,000$

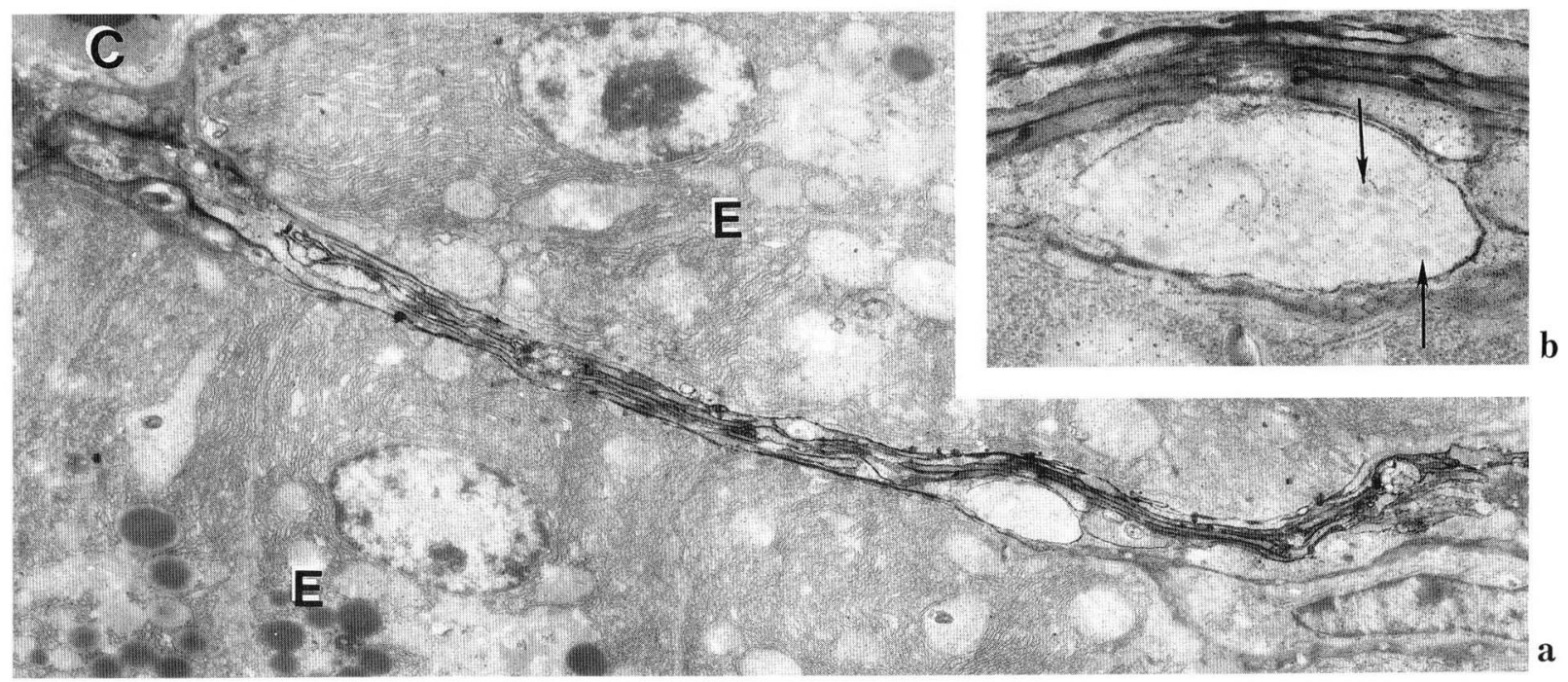

Fig. 9. a. AChE-positive nerve bundles running between acini. $C$ capillary, $E$ exocrine tissue. $\times 4,500$. b. High magnification of the varicosity formed in the way of the AChE-positive nerve bundle. The AChE activity is seen in the periaxolemma. This varicosity contains a few large dense-cored vesicles (arrows) and many small clear vesicles. $\times 19,000$ 
were also recognized within the axons which were not varicose in nature. Terminals showing AChE activity were often found in the walls of secretory ducts and also contacted the epithelial cells of intercalated ducts.

AChE-positive nerve bundles or terminals were found less frequently in the endocrine tissue than in the exocrine tissue, and were detected less in A-islets than in B-islets. Although most of the AChE-positive fibers in A-islets were found to run along the capillary side of the A-cell membrane, they rarely seemed to form synaptic contacts with A-cells. AChE-positive nerve terminals which contained many small clear vesicles came into contact mainly with D-cells in the A-islet. Sometimes terminals of this kind seemed to penetrate deeply into the D-cells (Fig. 10). AChE-
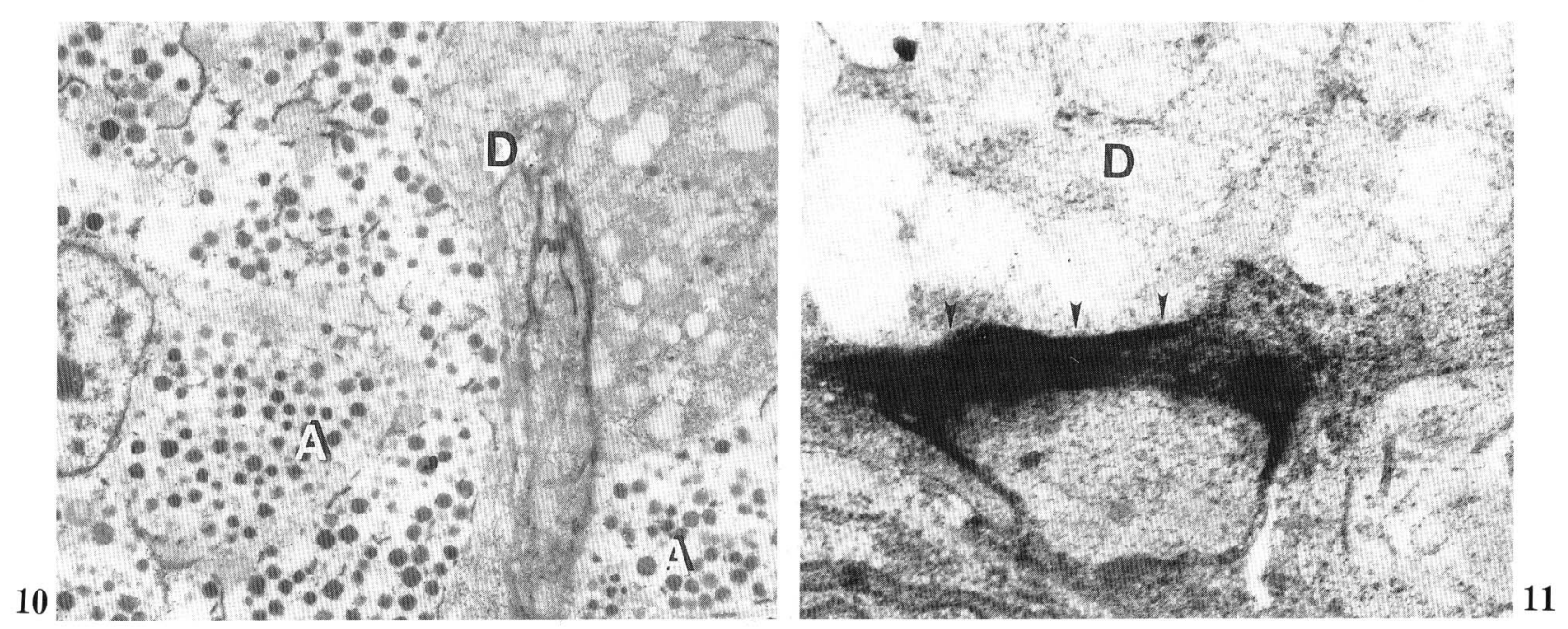

Fig. 10. AChE-positive nerve fibers apparently penetrating a D-cell $(D)$ in an A-islet. AChE reaction products are observed in the nuclear envelopes and rough endoplasmic reticulum of A-cells $(A) . \times 4,800$

Fig. 11. AChE-positive nerve terminal contacting a D-cell (D). Intense AChE activity (arrowheads) appears between the $\mathrm{D}$-cell and the terminal. $\times 36,000$

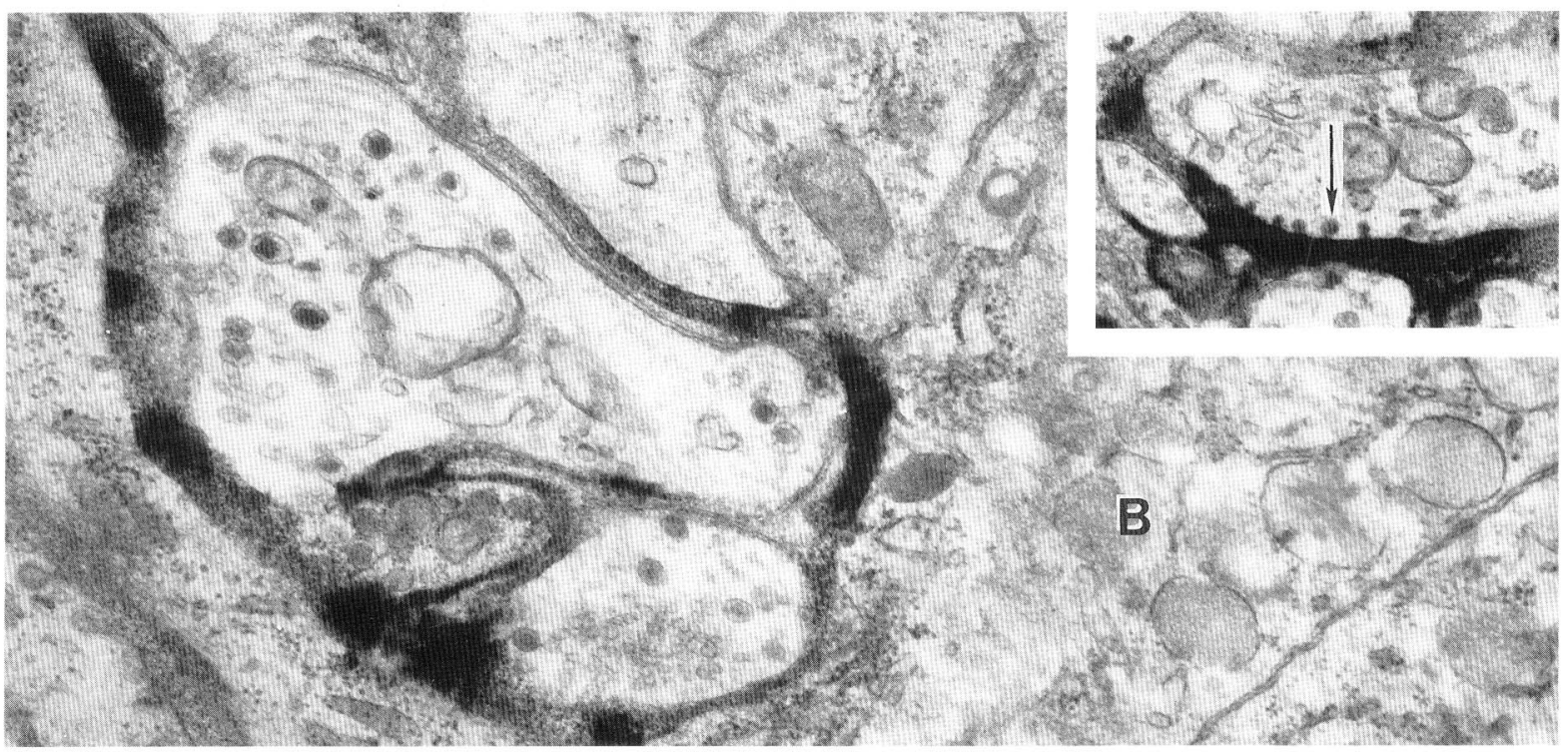

Fig. 12. AChE-positive nerve terminals in close contact with a B-cell. The AChE activity is seen at their periaxolemmal spaces. The terminals contain a few large dense-cored vesicles and many small clear vesicles. $\times 30,750$. Inset. An image suggesting the release of small clear vesicles in an invaginated shape $($ arrow $) . \times 28,000$ 
positive nerve terminals containing a few large dense-cored vesicles along with many small clear vesicles were often in contact with D-cells (Fig. 11). The reaction products of $\mathrm{AChE}$ were condensed between the D-cell membrane and the axolemma of the terminal.

As mentioned above, A-islets were weakly positive in $\mathrm{AChE}$ reaction. Electron microscopic observation indicated that it was the A-cell that caused this reaction. In the A-cell, AChE reaction products were detected between the nuclear envelopes and in the cisternae of the rough endoplasmic reticulum (Fig. 10).

AChE-positive nerve terminals occurred also in B-islets. In most cases several AChE-positive terminals grouped together around the B-cells, and contained a few large dense-cored vesicles and many small clear vesicles (Fig. 12). Several terminals containing small clear vesicles penetrated into the B-cells. AChE activity was observed in the membrane of terminals and spaces of the endoneurium. It seemed possible that invaginations in the terminal showing AChE activity might correspond to the release of small clear vesicles, judging from their size and shape (Fig. 12, inset).

\section{DISCUSSION}

Histochemical staining of $\mathrm{AChE}$ has been widely used for the identification of cholinergic neurons. When AChE histochemistry was carried out in cholinergic neurons of the central nervous system, AChE reaction products were observed in the cisternae of the nuclear envelope, rough endoplasmic reticulum and Golgi apparatus (LEwIS and SHUTE, 1966). However, as AChE occurs widely in nervous and related elements, the specificity of AChE staining for cholinergic neurons has often been disputed (SILVER, 1974). A consensus concerning the distribution of $\mathrm{AChE}$ and choline acetyltransferase (ChAT) - which is a more specific marker of cholinergic neurons (FIBIGER, 1982; HöKFELT et al., 1984)-has been reported for the central nervous system. Such regions as the substantia nigra, locus coeruleus and raphe nuclei in the central nervous system also stained positively for $\mathrm{AChE}$ and showed the same intracellular distribution for this enzyme as in the other central cholinergic neurons (HENDERSON and GREENFIELD, 1984). However, these regions have been known to contain non-cholinergic cells showing no ChAT activity (MizuKawa et al., 1986). The basis by which AChEstained neurons were identified as cholinergic depend- ed upon two criteria: the coincidence of $\mathrm{AChE}$ and ChAT in corresponding neurons in comparable sections, and higher contents of $\mathrm{AChE}$ in those neurons than in other types of neurons (SCHWABER et al., 1987).

TRANDABURU (1974) reported a similar distribution of the AChE reaction products in intrapancreatic ganglion cells of two avian species: the pigeon and magpie. Our present study confirms the occurrence of AChE-positive ganglion cells among the acini and in the connective tissue septa of the chicken pancreas. The intracellular distribution of AChE reaction products in these ganglion cells coincides with that in cholinergic neurons in the central nervous system. An AChE-positive neuron, as discussed above, is not necessarily cholinergic, but the terminals of the intrapancreatic ganglion cells displayed small clear vesicles regarded as the cholinergic type, and $\mathrm{AChE}$ activity was concentrated on the vesicles. Therefore, ChAT activity, which has not been pursued in these ganglion cells, remains to be proven.

In most mammalian species a rich supply of autonomic nerves to the exocrine and endocrine pancreas can be recognized. Autonomic nerves enter the pancreas along with the blood vessels and form a perivascular plexus (RICHINS, 1945; Coupland, 1958). They are distributed to the muscle layer of pancreatic ducts (GARRETT et al., 1973), acini and pancreatic islets (RICHINS, 1945; COUPLAND, 1958; ESTERHUIZEN et al., 1968; STACH, 1974; STACH and RADKE, 1982; モAKOMY and CHODKOWSKA, 1984; RADKE et al., 1985). Acinar cells of the mammalian pancreas are likely innervated only by terminals containing many small clear vesicles, i.e., cholinergic type terminals (Forss MANN and GREENBERG, 1978). In the domestic fowl, nerve endings containing small agranular vesicles have been demonstrated to contact the acinus (DAHL, 1973). AChE-positive nerve fibers arising from the perivascular plexus enter the parenchyma and richly supply the exocrine tissue (PURWAR, 1974, chicken, 1976, grey partridge; TRANDABURU, 1974, pigeon and magpie). The vascular relationships of the AChEpositive nerves in the avian pancreas corresponds to the situation in mammals.

The present study showed AChE-positive nerves reaching the pancreas along with the pancreaticoduodenal artery and its branches. In the lobule, they formed nerve plexuses around arteries and pancreatic ducts. AChE-positive fibers from the perivascular plexus were seen to proceed between acini, forming, on their way, AChE-positive varicosities apparently terminating on acinar cells. Innervation of the exocrine pancreas by AChE-positive nerves seems to be common to the avian and mammalian pancreas. 
In many species of mammals, pancreatic islets include ganglion cells and, moreover, are richly supplied with nerve fibers. The endocrine pancreas is more densely innervated than the exocrine part in the rat, cat and rabbit (CouPLAND, 1958). Both adrenergic and cholinergic nerves supply the three types of islet cells, though there are species differences in the relative amounts of these two fiber types in mammals (KobayASHi and Fujita, 1969; WoOdS and PoRTe, 1974). Cholinergic nerves form a peri-insular plexus (Coupland, 1958; STACH and RADKE, 1982; AMENTA et al., 1983; ŁAKOMY and CHODKOWSKA, 1984) and then are destined to islet cells (RICHINS, 1945; ESTERHU. IZEN et al., 1968; STACH, 1974; THOMAS and FINDLAY, 1978; RADKE et al., 1985). Observations on the innervation of the mammalian pancreatic islet are thus essentially consistent, whereas those on the avian pancreatic islet differ conspicuously among authors.

In the grey partridge, PURWAR (1976) demonstrated a large number of ganglion cells appearing in lobules in association with islets. In contrast, KOBAYASHI and FujITA (1969) claimed that pancreatic islets in the pigeon seemed to lack innervation. In the present study, none of islets contained ganglion cells, but nerve fibers were found regularly. In contrast to the findings in mammals, the chicken endocrine pancreas was less densely innervated than the exocrine tissue. This may be partly ascribed to the absence of ganglion cells in the chicken pancreatic islet. AChEpositive nerves are found in both A- and B-islets, though more densely in the latter. It was recognized that there was a difference in the innervation pattern between the $\mathrm{A}$ - and B-islets. The AChE-positive nerve fibers were gathered around capillaries in the A-islets, whereas they formed a peri-insular plexus in the B-islets. Moreover, our previous study demonstrated that D-cells in each islet of the chicken are mostly in contact with Type II nerve terminals containing some large dense-cored and many small clear vesicles (WATANABE and Yasuda, 1977). An immunohistochemical study with somatostatin antiserum revealed that D-cells of the chicken were dispersed within the A-islet in close relationship with the capillaries, and formed one or more layers at the periphery of the B-islet (IwANAGA et al., 1983). Considering these findings, a difference in the innervation pattern between the A- and B-islets seems to be caused by the varying arrangement of D-cells in both islets.

WATARI (1968) found terminals which contained both large dense-cored and small clear vesicles in the pancreatic islets of the pigeon. DAHL (1973) demonstrated nerve endings containing many small agranular vesicles in chicken pancreatic islets. Our previous electron microscopic study revealed the existence of Type II terminals containing many small clear vesicles and a variable number of large densecored vesicles in chicken pancreatic islets (WATANABE and YASUDA, 1977). This terminal corresponds to the typical cholinergic terminal in the central and peripheral nervous system in mammals (BURNSTOCK, 1979). In the present study we observed that the small clear vesicles were numerous in the AChE-positive nerve terminals of the chicken pancreas. Thus it seems probable that the nerve fibers in question are cholinergic.

The electron microscopic observations in this study revealed that the $\mathrm{AChE}$-positive endings are mainly in contact with B- and D-cells. This indicates that the cholinergic system may play an important role in the regulation of insulin and somatostatin release. We were not able to detect $\mathrm{AChE}$-positive terminals on A-cells. It seems reasonable to postulate that the AChE-positive fibers play a less important role in the regulation of glucagon release, if at all. We have also reported terminals of Type IV nerve fibers on A-cells (WATANABE and YASUDA, 1977). Terminals of this type contain numerous small densecored and a few large dense-cored vesicles; this feature corresponds to that of adrenergic terminals (BURNSTOCK, 1979). This view is supported by the finding that nerve fibers with formaldehyde-induced fluorescence were more numerous in A-islets than in $\mathrm{B}$-islets (unpublished data). It is probable that adrenergic, and not cholinergic, nerves are mainly involved in the regulation of glucagon secretion from A-cells.

\section{REFERENCES}

Amenta, F., C. Cavallotti, M. De Rossi, F. Tonelli and F. Vatrella: The cholinergic innervation of human pancreatic islets. Acta Histochem. 73: 273-278 (1983).

Burnstock, G.: The ultrastructure of autonomic cholinergic nerves and junctions. Prog. Brain Res. 49: 3-21 (1979).

Coupland, R. E.: The innervation of pancreas of the rat, cat and rabbit as revealed by the cholinesterase technique. J. Anat. 92: 143-149 (1958).

DAHL, E.: The fine structure of the pancreatic nerves of the domestic fowl. Z. Zellforsch. 136: 501-510 (1973).

Esterhuizen, A. C., T. L. B. Spriggs and J. D. Lever: Nature of islet-cell innervation in the cat pancreas. Diabetes 17: 33-36 (1968).

Fibiger, H. C.: The organization and some projections of cholinergic neurons of the mammalian forebrain. 
Brain Res. Rev. 4: 327-388 (1982).

Forssmann, W. G. and J. Greenberg: Innervation of the endocrine pancreas in primates. In: (ed. by) R.E. Coupland and W. G. Forssmann: Peripheral neuroendocrine interaction. Springer, Berlin, 1978 (p. 124133).

Garrett, J. R., P. Alm and S. Lenninger: Smooth muscle of the pancreatic duct of the cat and its innervation. Experientia 29: 842-844 (1973).

Henderson, Z. and S. A. Greenfield: Ultrastructural localization of acetylcholinesterase in substantia nigra: a comparison between rat and guinea pig. J. Comp. Neurol. 230: 278-286 (1984).

Hökfelt, T., O. Johansson and M. Goldstein: Chemical anatomy of the brain. Science 225: 1326-1334 (1984).

Iwanaga, T., R. YUI and T. FuJITA: The pancreatic islet of the chicken. In: (ed. by) S. Mikami, K. Homma and M. WADA: Avian endocrinology. Japan Scientific Societies Press, Tokyo, 1983 (p. 81-94).

KARNovsky, M. J. and L. Roots: A "direct-coloring" thiocholine method for cholinesterases. J. Histochem. Cytochem. 12: 219-221 (1964).

KobayAshi, S. and T. FuJita: Fine structure of mammalian and avian pancreatic islets with special reference to D cells and nervous elements. Z. Zellforsch. 100 : 340-363 (1969).

Kudo, S.: Fine structure of autonomic ganglion in the chicken pancreas. Arch. Histol. Jap. 32: 455-497 (1971).

Łлкому, M. and D. Cноркоwsка: Cholinergic innervation of pig pancreas. Acta Histochem. 75: 63-68 (1984).

LEwis, P. R. and C. C. D. Shute: The distribution of cholinesterase in cholinergic neurons demonstrated with the electron microscope. J. Cell Sci. 1: 381-390 (1966).

-: An electron-microscopic study of cholinesterase distribution in the rat adrenal medulla. J. Microsc. 89: 181-193 (1969).

Mizukawa, K., P. L. McGeer, H. Tago, J. H. Peng, E. G. MCGEER and H. Kimura: The cholinergic system of the human hindbrain studied by choline acetyltransferase immunohistochemistry and acetylcholinesterase histochemistry. Brain Res. 379: 39-55 (1986).

Nakamura, T. and K. Torigoe: Simultaneous visualization of catecholamine fluorescence and cholinesterase activity in the peripheral autonomic nerve. Acta Histochem. Cytochem. 12: 569 (1979).

PURwar, R. S.: Comparative neurohistological observations on the intrinsic innervation of Langerhans in Gallus domesticus (white leghorn) and Rattus rattus rufescens (Indian black rat). Mikroskopie 30: 150-154 (1974)

-: Neuro-histochemical observations on the pancreas of Francolinus pondicerianus (grey partridge or safed teeter) as revealed by the cholinesterase technique. Z. Mikrosk.-anat. Forsch. 90: 1009-1016 (1976).

RADKE, R., M. RADKE and C. RADKE: Light- und elektronenmikroskopische Untersuchungen zur Innervation des exocrinen Pankreas. Z. Mikrosk.-anat. Forsch. 99: 735-751 (1985).

Richins, C. A.: The innervation of the pancreas. J. Comp. Neurol. 83: 223-236 (1945).

Schwaber, J. S., W. T. Rogers, K. SAToh and H. C. Fibiger: Distribution and organization of cholinergic neurons in the rat forebrain demonstrated by computeraided data acquisition and three-dimensional reconstruction. J. Comp. Neurol. 263: 309-325 (1987).

Silver, A.: The biology of cholinesterases. North-Holland Publishing Company, Amsterdam, 1974.

Smith, P. H.: Pancreatic islets of the coturnix quail. A light and electron microscopic study with special reference to the islet organ of the splenic lobe. Anat. Rec. 178: 567-586 (1974).

STACH, W.: Morphologie und Histochemie von Synapsen im Bereich des Magen-Darm-Kanals. J. Neural Transm. Suppl. 11: 79-101 (1974).

STACH, W. and R. RADKE: Zur Innervation der Langerhansschen Inseln. Licht- und elektronenmikroskopische Untersuchungen am Pankreas von Laboratoriumstieren. Endokrinologie 79: 210-220 (1982).

Thomas, N. W. and J. A. Findlay: Innervation of the endocrine pancreas in the Mongolian gerbil (Meriones unguiculatus). In: (ed. by) R. E. Coupland and W. G. Forssmann: Peripheral neuroendocrine interaction. Springer, Berlin, 1978 (p. 134-143).

TrandabURU, T.: Ultrastructural and acetylcholinesterase investigations on the pancreas intrinsic innervation of two bird species (Columba livia domestica $\mathrm{Gm}$. and Euodice cantans $\mathrm{Gm}$.). Gegenbaurs Morphol. Jahrb. 120: 888-904 (1974).

W atanabe, T. and M. Yasuda: Electron microscopic study on the innervation of the pancreas of the domestic fowl. Cell Tiss. Res. 180: 453-465 (1977).

WATARI, N.: Fine structure of nervous elements in the pancreas of some vertebrates. Z. Zellforsch. 85: 291-314 (1968).

Woods, S. C. and D. Porte, Jr.: Neural control of the endocrine pancreas. Physiol. Rev. 54: 596-619 (1974).

Dr. Tohru WatanaBE

Department of Veterinary Anatomy

Faculty of Agriculture, Nagoya University

Furoh-cho, Chikusa-ku

Nagoya, 464 Japan

渡辺徹

464 名古屋市千種区不老町

名古屋大学農学部

家畜解剖学教室 